\title{
Genetic Evaluation for Additive and Dominance Effects by Animal Models and Its Effect on Genetic Gains in a Small MOET Beef Cattle Population
}

\author{
Takafumi IsHIDA and Fumio MUKaI \\ Faculty of Agriculture, Kobe University \\ Nada-ku, Kobe-shi 657
}

(Received November 5, 1992)

\begin{abstract}
Simulated selection and mating was carried out in a small MOET beef cattle population with a gene effect model to examine the effect of dominance deviations on genetic gains. The population was assuned to have overlapping generations, and to be composed of 60 animals in each generation. A trait, such as growth trait, was assumed to be recorded in both sexes, and controlled by 64 loci with both additive and dominance effects. Gene frequencies of the favorable alleles were set at $0.2,0.5$ and 0.8 to study the effect of gene frequency. Heritability in the broad sense, was set at 0.60 . Each donor produced four progenies by MOET per generation. Five males and 15 females were selected on breeding values predicted by animal model BLUP taking into account only additive effects or additive and dominance effects at each generation, for six generations. It was concluded that highly accurate predictions of breeding values with only small bias may be obtained by using a model that accounts for dominance effects. This result is most clearly observed when gene frequency is moderate, that is, when selection was carried out in a population originated from cross breeding. This model may be expected to increase genetic gains slightly. Therefore it appears necessary to account for dominance effects, if calculation time is available and costs are reasonable, when selection is carried out in a MOE'T population.
\end{abstract}

Anim. Sci. Technol. (Jpn.) 64 (7): 669-677, 1993

Key words : dominance effect, MOET, animal model, genetic gain, simulation

Currently best linear unbiased prediction (BLUP) methodology using an animal model is widely applied to evaluate additive genetic effect in farm livestock, especially dairy and beef cattle. However, more complicated genetic relationships arise in populations produced from recent reproductive technologies such as multiple ovulation and embryo transfer (MOET), cloning etc. It is, therefore, necessary to consider the dominance relationships along with the additive relationships in order to evaluate additive genetic values precisely if a trait under consideration is controlled by both additive and dominance effects.

The efficiency of MOET breeding schemes compared to the traditional breeding methods has been investigated by TANAKA et $a l^{12}{ }^{12}$, Nicholas and SMTth ${ }^{9)}$, Gearheart et $a l^{43}$ and RUANe and ThOMPSON ${ }^{10)}$. They concluded that MOET breeding schemes contribute to the reduction of generation interval, improve on the accuracy of selection for dams, and then significantly increase the rate of genetic progress. However, only few studies have evalu- 
ated non-additive effects.

HENDERSON $^{6)}$ presented a BLUP procedure for predicting non-additive genetic effect in non-inbred populations. However, if the population is inbred and dominance effects are present, predictions of additive genetic values become biased ${ }^{8}$. Under such conditions, KENNEDY et $a l .{ }^{7}$ proposed the inclusion of the inbreeding coefficient in the model as a covariate, in addition to additive and dominance relationship matrices. UIMARI and KENNEDY ${ }^{14)}$ and DE BOER and VAN ARENDONK ${ }^{3)}$ examined this method through computer simulation and found that the procedure provides unbiased predictions of additive effects and dominance deviations in inbred populations.

This paper examined the genetic gains on a trait controlled by both additive and dominance effects in a simulated small MOET beef cattle population with gene effect model.

\section{Materials and Methods}

Trait and population structure simulated: A single trait was simulated stochastically considering additive and dominance gene effects. The trait was assumed to be controlled by 64 loci with partial dominance (degree of dominance $=0.50$ ) at each locus and recorded in both sexes such as growth trait. Each locus has two alleles ( $A$ and a) and gene frequencies of the favorable allele (A) in the base population were set at $0.2,0.5$ or 0.8 to study the effect of gene frequency. That is, we assumed that at the gene frequency of 0.2 there has never been any selection for the target trait, so the genetic level is low in this base population, and at the gene frequency of 0.8 it was assumed that selection was carried out in the base population prior to the start of genetic evaluation and further selection. Also, in case of gene frequency of 0.5 , we assumed a population newly produced by cross breeding. In our another study (data not shown), it was found that the effect of recombination rate between 0.5 and 0.25 on the genetic gains was small in short term selection. So recombination rate between adjacent loci was assumed to be 0.25 , bacause linkage groups are of ten observed in some mammalian species ${ }^{5)}$. Heritability in broad sense was set at 0.6 in the base population. So heritability in narrow sense was 0.57 , 0.53 and 0.52 at gene frequencies $0.2,0.5$ and 0.8 , respectively, because environmental variances were the same at each gene frequency.

The population comprised of 60 animals before selection. Five males and 15 females were selected based on breeding values (PBVs) predicted using all information except progeny records in each generation. Three donors were mated randomly to one sire, allowing full-sib mating. Each donor produced 4 progenies per collection and these progenies were randomly assigned to one of 4 seasons regarded as a fixed effect. Sex of progeny was determined with probability of 0.5 . Sires were used for only 1 generation and dams for 1 to 3 generations. However, they could be culled within the allowable active period according to their ranking on PBVs.

Generation of animal records : Records of individuals in the base population were generated for the effects represented in the following model :

$$
y_{i j k}=U_{i}+S_{j}+a_{i j k}+d_{i j k}+e_{i j k}
$$

where $y_{i j k}$ is the record of the $k$-th animal in the $i$-th generation and the $j$-th season; $U_{i}$ is the effect peculiar to the $i$-th generation distributing with mean 0 and variance $0.01 ; S_{j}$ is the effect of the $j$-th season with levels of $-0.2,-0.1,0.1$ or $0.2 ; \mathrm{a}_{\mathrm{ijk}}$ is the additive genetic (breeding) value of the $k$-th animal ; $\mathrm{d}_{\mathrm{ijk}}$ is the dominance deviation of the $\mathrm{k}$-th animal ; and $e_{i j k}$ is a random environmental effect. Individual genotypes were generated by assigning allele $\mathrm{A}(=1)$ or $\mathrm{a}(=0)$ according to the initial gene frequency of the favorable allele (A) of $0.2,0.5$ or 0.8 . Breeding values were determined by summing up additive gene effects $(A=1$ and $a=0)$ over 64 loci, and dominance deviations by multiplying the num- 
ber of heterozygotes by 0.5. For convenience, the distribution of phenotypic values was standardized with mean 0 and unit variance, therefore breeding values and dominance deviations were distributed $\mathrm{N}\left(0, \sigma_{\mathbf{a}_{0}}^{2}\right)$ and $\mathrm{N}$ $\left(0, \sigma_{\mathrm{d} 0}^{2}\right)$ respectively, where $\sigma^{2}{ }_{\mathrm{a} 0}$ and $\sigma_{\mathrm{d} 0}^{2}$ indicate additive and dominance variance in the base population respectively. Environmental deviations were generated from random deviates distributed $\mathrm{N}\left(0, \mathrm{O}_{\mathrm{e}}^{2}\right)$ and were assumed to be constant during selection. Genetic and environmental covariances were set to zero.

Records of progeny were generated in the same manner as those of the base population animals. However, breeding values and dominance deviations were determined based on the zygotes formed by gametes from sire and dam, accounting for recombination.

Models for genetic evaluation: Breeding values and/or dominance deviations were predicted by two kinds of mixed linear models as follows:

[Model 1] $\mathrm{y}_{\mathrm{ijk}}=\mathrm{U}_{\mathrm{i}}+\mathrm{S}_{\mathrm{j}}+\mathrm{a}_{\mathrm{ijk}}+\mathrm{rF}_{\mathrm{ijk}}+\mathrm{e}_{\mathrm{ijk}}$

[Model 2] $y_{i j k}=U_{i}+S_{j}+a_{i j k}+d_{i j k}+r F_{i j k}$

$$
+e_{i j k}
$$

where $r$ is the linear regression coefficient of the record on inbreeding coefficient $F_{i j k}$, and other symbols are the same as those of the previous equation. These models include regression on inbreeding coefficient as a covariate to take account of inbreeding depression" Model 1 takes account of additive genetic effect only, and Model 2 includes dominance effect in addition to additive genetic effect. Dominance deviation was evaluated as $\hat{\mathrm{d}}_{\mathrm{ijk}}+$ $\hat{\mathrm{r}} \mathrm{F}_{\mathrm{ijk}}$ according to UIMARI and KENNEDY ${ }^{14)}$ and De Boer and VAN AREndonK ${ }^{3}$.

The mixed model equation for Model 1 is

$$
\begin{aligned}
& {\left[\begin{array}{ll}
\mathrm{X}^{\prime} \mathrm{X} & \mathrm{X}^{\prime} \mathrm{Z} \\
\mathrm{Z}^{\prime} \mathrm{X} & \mathrm{Z}^{\prime} \mathrm{Z}+\alpha \mathrm{A}^{-1}
\end{array}\right]\left[\begin{array}{l}
\tilde{\mathrm{b}} \\
\hat{\mathrm{a}}
\end{array}\right]=\left[\begin{array}{l}
\mathrm{X}^{\prime} \mathrm{y} \\
\mathrm{Z}^{\prime} \mathrm{y}
\end{array}\right],} \\
& \alpha=\sigma_{\mathrm{e} \mathcal{O}}^{2} \sigma_{\mathrm{a} 0}^{2},
\end{aligned}
$$

and for Model 2 is

$$
\left[\begin{array}{ll}
X^{\prime} X & X^{\prime} Z \\
Z^{\prime} X & Z^{\prime} Z+\sigma^{2}{ }_{0} G^{-1}
\end{array}\right]\left[\begin{array}{l}
\tilde{b} \\
\hat{g}
\end{array}\right]=\left[\begin{array}{l}
X^{\prime} y \\
Z^{\prime} y
\end{array}\right] .
$$

Where $\mathrm{X}$ and $\mathrm{Z}$ stand for incidence matrices relating the records to fixed and random factors and $\mathrm{A}$ for additive relationship matrix. $G$ is derived from $A$ and the dominance relationship matrix $\mathrm{D}^{6)}$ as follows :

$$
\mathrm{G}=\sigma_{\mathrm{a}_{0}}^{2} \mathrm{~A}+\sigma_{\mathrm{d} 0}^{2} \mathrm{D} \text {. }
$$

Additive and dominance relationship matrices were derived from gametic relationship matrix taking account of inbreeding according to SMITH $^{11}$. Breeding values $(\hat{a})$ and dominance deviations ( $\hat{\mathrm{d}})$ in equation [2] were derived as follows :

$$
\begin{aligned}
& \hat{\mathrm{a}}=\sigma_{{ }_{a 0}}^{2} A G^{-1} \hat{\mathrm{g}} \\
& \hat{\mathrm{d}}=\sigma_{{ }_{0} 0}^{2} D G^{-1} \hat{\mathrm{g}} .
\end{aligned}
$$

The above mentioned mixed models were applied to simulated selection data from the base population to the latest generation, and animals were evaluated by using all records and pedigree information available up to a given selection stage. Parents for the next generation were selected on predicted breeding values among parents and progeny in each generation. This selection contiuned for 6 generations. Dams used at the previous generation and candidates for selection were evaluated using all available information, and selected animals were mated randomly to produce progeny for the next generation. The same base population was used in respective replication for purposes of comparing different evaluation methods (Model 1 and 2). All results were shown as means of 20 replicated runs.

\section{Results and Discussion}

Table 1 shows changes of average true and predicted total genetic values (TGVs and PGVs), comprising of breeding values and dominance deviations, at the 2nd, 4-th and 6-th generations through selection at three gene frequencies.

For all gene frequencies, the average TGVs of generations selected under Model 2 tended to be higher than those selected under Model 1 at the 6 -th generation. TGVs were highest at gene frequency 0.2 and lowest at gene frequency 0.8 , 
ISHIDA and MUKAI

Table 1. Comparison of average true total genetic values (TGVs) and average predicted total genetic values (PGVs) at the 2nd, 4-th and 6-th generations ${ }^{1,21}$

\begin{tabular}{|c|c|c|c|c|c|c|c|}
\hline \multirow{3}{*}{ Generation } & & \multicolumn{6}{|c|}{ Favorable Gene Frequency } \\
\hline & & \multicolumn{2}{|c|}{0.2} & \multicolumn{2}{|c|}{0.5} & \multicolumn{2}{|c|}{0.8} \\
\hline & & Model 1 & Model 2 & Model 1 & Model 2 & Model 1 & Model 2 \\
\hline \multirow[t]{2}{*}{2} & TGV & $1.45^{\mathrm{a} 31}$ & $1.46^{\mathrm{a}}$ & $0.95^{b}$ & $0.95^{b}$ & $0.58^{c}$ & $0.58^{c}$ \\
\hline & PGV & $1.33^{\mathrm{b}}$ & $1.23^{\mathrm{c}}$ & $1.15^{\mathrm{a}}$ & $0.99^{b}$ & $0.95^{\mathrm{a}}$ & $0.82^{b}$ \\
\hline \multirow[t]{2}{*}{4} & TGV & $2.57^{\mathrm{ab}}$ & $2.55^{\mathrm{a}}$ & $1.66^{\mathrm{b}}$ & $1.69^{b}$ & $0.95^{\mathrm{c}}$ & $0.97^{\mathrm{c}}$ \\
\hline & PGV & $2.49^{b}$ & $2.32^{\mathrm{c}}$ & $2.11^{\mathrm{a}}$ & $1.75^{\mathrm{b}}$ & $1.76^{\mathrm{a}}$ & $1.50^{\mathrm{b}}$ \\
\hline \multirow[t]{2}{*}{6} & TGV & $3.68^{b}$ & $3.87^{\mathrm{a}}$ & $2.20^{d}$ & $2.32^{c}$ & $1.29^{c}$ & $1.32^{\mathrm{c}}$ \\
\hline & PGV & $3.60^{\mathrm{b}}$ & $3.35^{\mathrm{c}}$ & $2.98^{\mathrm{a}}$ & $2.47^{\mathrm{b}}$ & $2.52^{\mathrm{a}}$ & $2.16^{b}$ \\
\hline
\end{tabular}

1) Total genetic standard deviation unit.

2) Both averages of TGVs and PGVs are significantly different among three gene frequencies in all generations and models $(p<0.001)$.

3) Averages of TGVs and PGVs with different superscript within each gene frequency and generation are significantly different between Model 1 and $2(p<0.05)$.

Table 2. Correlation coefficients between true total genetic values (TGVs) and predicted total genetic values (PGVs), and mean squared error (MSE) ${ }^{11}$ of predicted total genetic values (PGVs) at the 6 -th generation

\begin{tabular}{lccccccc}
\hline \hline & \multicolumn{3}{c}{$\begin{array}{c}\text { Correlation } \\
\text { coefficients }\end{array}$} & & \multicolumn{3}{c}{ MSE $^{11}$} \\
\cline { 2 - 4 } \cline { 6 - 8 } & $0.2^{21}$ & 0.5 & 0.8 & & $0.2^{21}$ & 0.5 & 0.8 \\
\hline Model 1 & 0.73 & 0.62 & 0.49 & & 0.34 & 0.89 & 1.71 \\
Model 2 & 0.74 & 0.68 & 0.53 & & 0.61 & 0.28 & 0.87 \\
\hline
\end{tabular}

1) MSE represents measurement of predicted error variance plus squared bias.

2) Favorable gene frequency.

for both models. This was caused by the differences in the genetic levels in the base generation according to initial gene frequencies. When favorable gene frequenecy is 0.2 , average total genetic values are low in the base population and the frequency of the genotype favored for the target trait increases under selection with progressing generation, so the genetic values also get higher. On the other hand, when gene frequency is 0.8 , average total genetic values in the base population are already at a high level because assumed previous selection. In this population, therefore, there is little scope to increase genetic value, so average total genetic values do not increase so rapidly under selection.
The average PGVs for the 6 -th generation were underestimated at $2 \%$ for Model 1 and 13 $\%$ for Model 2, when favorable gene frequency was low (0.2). On the other hand, with moderate to high gene frequency $(0.5$ and 0.8$)$, the PGVs were overestimated at $35-95 \%$ for Model 1 and at 6-64\% for Model 2. These biases may be caused by inbreeding depression induced by partial dominance, and that depression was not fully accounted for in the analysis ${ }^{8)}$. As shown in Table 2 , the correlation coefficients between TGVs and PGVs, as well as mean squared error of PGVs (MSE) at the 6-th generation, indicate that inbreeding depression was better accounted for by Model 2 than by Model 1. From these results, the 
Genetic Evaluation in a MOET Population

Table 3. Comparison of average true breeding values (TBVs) and average predicted breeding values (PBVs) at the 2 nd, 4-th and 6-th generations 1,21

\begin{tabular}{|c|c|c|c|c|c|c|c|}
\hline \multirow{3}{*}{ Generation } & & \multicolumn{6}{|c|}{ Favorable Gene Frequency } \\
\hline & & \multicolumn{2}{|c|}{0.2} & \multicolumn{2}{|c|}{0.5} & \multicolumn{2}{|c|}{0.8} \\
\hline & & Model 1 & Model 2 & Model 1 & Model 2 & Model 1 & Model 2 \\
\hline \multirow[t]{2}{*}{2} & TBV & $1.32^{\mathrm{ab} 3 \mathrm{l}}$ & $1.32^{\mathrm{ab}}$ & $1.10^{\mathrm{ab}}$ & $1.11^{\mathrm{ab}}$ & $0.93^{\mathrm{ab}}$ & $0.91^{\mathrm{ab}}$ \\
\hline & PBV & $1.33^{\mathrm{a}}$ & $1.29^{\mathrm{b}}$ & $1.15^{\mathrm{a}}$ & $1.07^{b}$ & $0.95^{\mathrm{a}}$ & $0.87^{\circ}$ \\
\hline \multirow[t]{2}{*}{4} & TBV & $2.43^{a}$ & $2.50^{\mathrm{a}}$ & $2.02^{\mathrm{ab}}$ & $2.09^{a b}$ & $1.59^{\mathrm{b}}$ & $1.62^{t}$ \\
\hline & PBV & $2.49^{\mathrm{a}}$ & $2.46^{a}$ & $2.11^{a}$ & $2.00^{b}$ & $1.76^{\circ}$ & $1.65^{b}$ \\
\hline \multirow[t]{2}{*}{6} & TBV & $3.58^{b}$ & $3.75^{\mathrm{a}}$ & $2.78^{b}$ & $2.91^{\mathrm{ab}}$ & $2.15^{c}$ & $2.22^{\mathrm{kx}}$ \\
\hline & PBV & $3.60^{\mathrm{ab}}$ & $3.59^{b}$ & $2.98^{a}$ & $2.80^{b}$ & $2.52^{\mathrm{a}}$ & $2.36^{b}$ \\
\hline
\end{tabular}

1) Additive genetic standard deviation unit.

2) Both averages of TBVs and PBVs are significantly different among three gene frequencies in all generations and models $(\mathrm{p}<0.01)$.

3) Averages of TBVs and PBVs with different superscript within each gene frequency and generation are significantly different between Model 1 and $2(p<0.05)$.

model accounting for only additive effect give predictions much biased from true values.

The changes of average true additive genetic values (true breeding values, TBVs) or genetic gains, and predicted breeding values (PBVs) in the 2nd, 4-th and 6-th generations are shown in Table 3. TBVs with Model 2 for the 6-th generation were $3-5 \%$ superior to those with Model 1 but the difference was not significant. Like TGVs, TBVs in the 6-th generation showed the highest value at gene frequency 0.2 , and the lowest at gene frequency 0.8 , reflecting the genetic level in the base population as mentioned above. At the 6-th generation, PBVs with Model 1 were significantly overestimated but with Model 2 there was no difference between TBVs and PBVs except at the gene frequency of 0.2 . This also supports the conclusion that the model accounting for only additive effect gives more biased predictions. In addition, standard deviations of means of replicated runs at the 6 -th generation were $0.40,0.45$ and 0.43 with Model 1, and 0.43, 0.43 and 0.37 with Model 2 at gene frequency 0.2 , 0.5 and 0.8 , respectively. These tended to be smaller under Model 2 than under Model 1, except in the case of gene frequency 0.2. This indicates that stable genetic progress in practical breeding may be expected with Model 2 at moderate frequency of the favorable allele.

The correlation coefficients between TBVs and PBVs, as well as MSE of PBVs in the 2nd 4-th and 6-th generations are shown in Table 4. For both Model 1 and Model 2, the correlation coefficients increased as the frequency of the favorable allele in the base population decreased. Heritabilities in narrow sense were $0.57,0.53$ and 0.52 for gene frequencies of 0.2 , 0.5 and 0.8 , respectively, so the accuracy of selection, which is a function of a variance ratio (heritability), became higher as gene frequency was lower. The correlation coefficients became smaller and MSE became larger with progressing generation regardless of initial gene frequencies and the models. The change of distribution of TBVs and PBVs and the amount of available additive genetic variance may also provide an explanation for the above results. The distribution became narrower and deviated from normal distribution through selection, and the additive variance decreased due to selection, pure random drift and accumulating inbreeding ${ }^{1,2)}$. So the correlation coefficients between TBVS 
Table 4. Correlation coefficients (Corr.) between true breeding values (TBVs) and predicted breeding values (PBVs), and mean squared error (MSE) ${ }^{1}$ of predicted breeding values (PBVs)

\begin{tabular}{|c|c|c|c|c|c|c|c|c|}
\hline \multirow{3}{*}{ Generation } & & \multicolumn{7}{|c|}{ Favorable Gene Frequency } \\
\hline & & \multicolumn{3}{|c|}{0.2} & \multicolumn{2}{|c|}{0.5} & \multicolumn{2}{|c|}{0.8} \\
\hline & & Model 1 & & Model 2 & Model 1 & Model 2 & Model 1 & Model 2 \\
\hline \multirow[t]{3}{*}{ Corr. } & 2 & 0.77 & & 0.77 & 0.66 & 0.66 & 0.54 & 0.54 \\
\hline & 4 & 0.77 & & 0.77 & 0.61 & 0.65 & 0.52 & 0.53 \\
\hline & 6 & 0.71 & & 0.71 & 0.58 & 0.60 & 0.46 & 0.46 \\
\hline \multirow[t]{3}{*}{$\mathrm{MSE}^{1 \prime}$} & 2 & 0.23 & & 0.23 & 0.26 & 0.25 & 0.29 & 0.28 \\
\hline & 4 & 0.24 & ! & 0.25 & 0.25 & 0.26 & 0.30 & 0.27 \\
\hline & 6 & 0.30 & $!$ & 0.33 & 0.37 & 0.29 & 0.44 & 0.31 \\
\hline
\end{tabular}

1) MSE represents measurement of predicted error variance plus squared bias.

Table 5. Percentage of homozygotes in all loci at the 2nd, 4-th and 6-th generations"

\begin{tabular}{|c|c|c|c|c|c|c|}
\hline \multirow{3}{*}{ Generation } & \multicolumn{6}{|c|}{ Favorable Gene Frequency } \\
\hline & \multicolumn{2}{|c|}{0.2} & \multicolumn{2}{|c|}{0.5} & \multicolumn{2}{|c|}{0.8} \\
\hline & Model 1 & Model 2 & Model 1 & Model 2 & Model 1 & Model 2 \\
\hline 2 & 63.1 & 63.2 & 53.3 & 53.6 & 74.9 & 74.8 \\
\hline 4 & 63.0 & 62.6 & 58.5 & 59.4 & 80.7 & 80.8 \\
\hline 6 & 64.2 & 63.8 & 63.7 & 63.9 & 85.0 & 85.7 \\
\hline
\end{tabular}

1) Percentage of homozygotes are significantly different among three gene frequencies in all generations and models $(p<0.05)$ except for between frequency 0.2 and 0.5 at the 6 -th generation with both models.

and PBVs within generation tended to be higher in the base population but these decreased gradually as generation number increased.

When favorable gene frequency was moderate (0.5), the correlation coefficients and MSE with Model 2 tended to be better than those with Model 1. However, at extreme gene frequencies $(0.2$ or 0.8$)$, the correlation coefficients with Model 2 were almost the same as those of Model 1. The MSE with Model 2 were comparable to the MSE with Model 1 , when the frequency was 0.2 . This indicates also that PBVs under Model 2 still include a large bias.

At low gene frequency (0.2), as shown in Table 5 , since the percentage of homozygotes did not increase from the base generation, percentage of heterozygotes remained large and did not change from the base generation. Thus there was a large dominance deviations at all generations as shown in Table 6. Therefore PBVs under Model 1, which does not account for dominance effect, include a large bias. PBVs under Model 2, which could account for dominance effect, also still include bias, because of the inclusion of bias associated with predicted dominance deviations. With gene frequency of 0.5 or 0.8 , the predicted values also included bias, but the trend through the generations was similar to those observed for the true values. On the other hand, at the gene frequency of 0.2 , the trend was different from those of the true values. This was caused by the occurrence of the highest percentage of heterozygosity and the largest dominance deviations as mentioned above. So the predicted values did not trace the trend of the true values. 
Table 6. Comparison of average true dominance deviations (True) and average predicted dominance deviations (Pred.)" under Model 2 at the $2 \mathrm{nd}, 4$-th and 6-th generations ${ }^{21}$

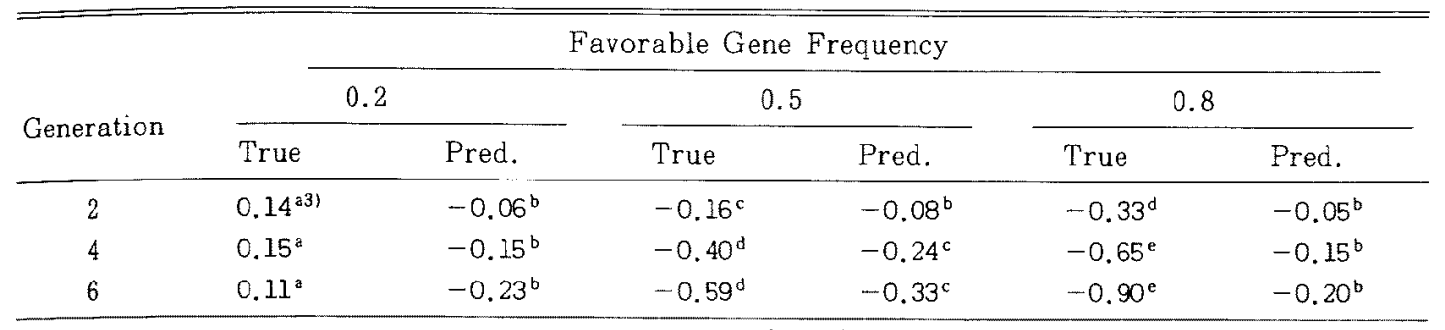

1) Predicted dominance deviation was evaluated by $\left(\tilde{d}_{i j k}+\dot{r} F_{i j k}\right)$.

2) Dominance genetic standard deviation unit.

3) Averages of true and predicted dominance deviations with different superscript within each generation are significantly different $(p<0.05)$.

Table 7. Changes of average inbreeding coefficients at the 2nd, 4-th and 6-th generations ${ }^{11}$

\begin{tabular}{|c|c|c|c|c|c|c|}
\hline \multirow{3}{*}{ Generation } & \multicolumn{6}{|c|}{ Favorable Gene Frequency } \\
\hline & \multicolumn{2}{|c|}{0.2} & \multicolumn{2}{|c|}{0.5} & \multicolumn{2}{|c|}{0.8} \\
\hline & Model 1 & Model 2 & Model 1 & Model 2 & Model 1 & Model 2 \\
\hline 2 & 0.05 & 0.05 & 0.05 & 0.05 & 0.05 & 0.04 \\
\hline 4 & 0.13 & 0.14 & 0.13 & 0.14 & 0.14 & 0.14 \\
\hline 6 & 0.21 & 0.22 & 0.20 & 0.21 & 0.21 & 0.23 \\
\hline
\end{tabular}

"Average inbreeding coefficients are not significantly different among three gene frequencies in all generations and models.

The differences between TBVs under Model 1 and TBVs under Model 2 for all generations were small at the highest gene frequency $(0.8)$. This may be attributed to the fact that, at this gene frequency, the percentage of homozygotes were largest compared with those of other gene frequencies. Thus the simulated dominance deviations were smallest at this gene frequency so Model 2 could not account for dominance effects fully and this caused the observed small differences between the two models.

The degree of inbreeding is shown in Table 7. In the 6-th generation, when gene frequency was moderate to low $(0.5$ and 0.2$)$, there was no large difference in the average inbreeding coefficients between Model 1 and Model 2. Also at a high gene frequency of 0.8 , the difference in inbreeding coefficients for Model 1 and Model 2 were not significant but tended to be higher under Model 2. In order to examine the effect of accumulating inbreeding on genetic gain and inbreeding depression a long term selection experiment is necessary. Toro et $a l^{133}$ studied genetic improvement by the MOET schemes in hierarchical and factorial mating systems under restricted inbreeding. They applied linear programming techniques for determining selection and mating policies. This methodology may be applied in order to minimize the accumulation of inbreeding through selection on predicted breeding values at moderate gene frequency.

It was also found that the linear regression coefficients of the records on inbreeding coefficients were $-1.25,-1.74$ and -0.90 under Model 1, and $-1.28,-2.05$ and -1.33 under Model 2, at gene frequencies of $0.2,0.5$ and 0.8 , respectively. With Model 2 and at moderate gene frequency of 0.5 , much inbreeding depres- 
sion was observed. This trend was the same as observed for the single locus model. The regression coefficients represent the value of -2 pqd in the single locus model, where $\mathrm{p}$ is gene frequency of the favorable gene, $q$ is gene frequency of its allele and $d$ is dominance effect. In this model, -2 pqd is smallest when $\mathrm{p}=0.5$.

It is concluded from these results that, for predicting breeding values, highly accurate predictions with small bias may be obtained by using models that account for dominance effects. This result is most clearly observed when gene frequency is moderate, that is, when selection was carried out in a population originated from line crossing or cross breeding. However, there were no large differences of genetic gains between the models. Judging from size of the correlation coefficients between TBVs and PBVs, similar animals may be selected as parents under both models regardless of the degree of bias. This means that when evaluating genetic values or trend, the model accounting for only additive effects gives overestimated predictions. So there is a fear of misunderstanding the genetic trend through selection. In addition, the model that accounts for dominance effect may be expected to increase genetic gains slightly when selection is carried out in a population, where more complicated dominance relationships between animals arise. The model that includes regression of phenotypic value on inbreeding coefficient without accounting for dominance effect (Model 1), is able to improve the degree of accuracy or reduce bias of predicted breeding values than those under the model which accounts for additive effect without the regression (data not shown). However, it was found to be inferior to the model accounting for dominance effect. It appears necessary to account for dominance effect, if calculation time is available and costs are reasonable. Further investigations on the estimation of dominance variance and the effect of the number of progeny produced using MOET on genetic gains in livestock population need to be carried out.

\section{References}

1) Bulmer, M.G., The effect of selection on genetic variability. Amer. Nat., 105: 201211. 1971.

2) Butmer, M.G., The effect of selection on genetic variability: a simulation study. Genet. Res., 28 : 101-117. 1976.

3) De BOER, I.J.M. and J.A.M. VAN ARENDONK, Prediction of additive and dominance effects in selected or unselected populations with inbreeding. Theor. Appl. Genet., 84 : 451-459. 1992.

4) Gearheart, W.W., C. Smith and G. TEEPKER, Multiple ovulation and embryo manipulation in the improvement of beef cattle: relative theoretical rates of genetic change. J. Anim. Sci., 67 : 2863-2871. 1989.

5) GeldermanN, H., Application of genome analysis in animal breeding. In Genome analysis in domestic animals. (GeLDZRMANN, H. and F. ELLENDORFF eds.) 291-323. VCH, Weinheim. Bundesrepublik Deutschland. 1990.

6) Henderson, C.R., Best linear unbiased prediction of nonadditive genetic merits in noninbred population. J. Anim. Sci., 60 : 111-117. 1985.

7) Kennedy, B.W., L.R. SchaefFer and D.A. SORENSEN, Genetic properties of animal models. J. Dairy Sci., 71 (Supp1. 2) : 1726. 1988.

8) Mäki-Tanila, A. and B.W. Kennedy, Mixed model methodology under genetic models with a small number of additive and non-additive loci. In Proc. 3rd World Congr. Genet. Appl. Livest. Prod. (Dickerson, G.E. and R.K. Johnson, eds.). Agric. Commun., Univ. Nebraska. Nebraska. XII : 443-448. 1986.

9) Nicholas, F.W. and C. Smith, Increased rates of genetic change in dairy cattle by embryo transfer and splitting. Anim. Prod., 36 : 341-353. 1983.

10) Ruane, J. and R. Thompson, Simulation of an adult multiple ovulation and embryo transfer (MOET) nucleus breeding scheme in dairy cattle. In New selection schemes in cattle. (KALM, E. and T. LIBORIUSSEN 
eds.) 72-80. Centre for Agricultural Publishing and Documentation, Pudoc Wageningen. Netherlands. 1989.

11) Sмттн, S.P., Dominance relationship matrix and inverse for an inbred population. Ohio State Univ. Mimeo. 1984.

12) Tanaka, H., T. Furukawa and $Y$. YAMADA, Breeding plan for beef cattle by embryo transfer I. Prediction of genetic gain in breeding stock. Jpn. J. Zootech. Sci., 53: 283-288. 1982. (in Japanese).

13) Toro, M., L. Silió and M. Pérez-Enciso,
A note on the use of mate selection in closed MOET breeding schemes. Anim. Prod., 53 : 403-406. 1991.

14) Uimari, P. and B.W. Kennedy, Mixed model methodology to estimate additive and dominance genetic values under complete dominance and inbreeding. In $4 \mathrm{th}$ World Congr. Genet. Appl Livest. Prod. (Hill, W.G., R. THOMPSON and J.A. Woolliams, eds.). Edinburgh. Scotland. XIII : 297 300. 1990.

\title{
MOET によって造成される肉用牛小集団での 相加的抢よび優性効果の遺伝的評価と その遺伝的改良量に及ぼす影響
}

\author{
石田孝史・向井文雄 \\ 神戸大学農学部, 神戸市灘区 657
}

\begin{abstract}
受精卵移植（MOET）によって造成される肉用牛小集団において，優忙効果が遺伝的改良量に及ぼ す影響を遗伝子効果を考慮した選抜交配シミュレーションを用いて検討した。集団は各世代 60 頭から なるとし，世代は重複するとした，対象形質は相加的拉よび優性効果を持っ64遗伝子座によって支配 され，また両性で観察されるとした，遺伝子頻度の影響を確加めるために形質に正の効果を持つ遗伝子 の頻度を $0.2,0.5$ および 0.8 とし，広義の遗伝率を 0.6 とした。また各胚提供雌は 1 世代につき 4 䫓 の後代を生産するとした，雄 5 頭, 雌 15 頭をアニマルモデル BLUP 法による育種価予測值によって 選抜し，この選抜交配を 6 世代にわたって行なった。育種価は相加的効果のみを考虑するモデルと儤性 効果をす考虑するモデルによって予想した，その結果，MOETの上うに個体間により多くの優性血縁 関保が生じる集団に扔いて育種価を予測する場合，優性効果をも考虑できるモデルによって，正確度が 高く，扁りの小さな予想值が得られる傾向が認められ，このことは中程度の遭伝子頻度，すなわ方新た に交雑などにより造成された集団で育種価予測值による選技を開始するような場合には特に顕著であっ たまた，このモデルによる青種価予測値を用いた選拻の結果，わずかながら高い遗伝的改良量が得ら れることが明らかとなり，MOETによる集団での遗伀的評価において，計算時間や貲用の制約がなけ れば镹性効果を考歷する必要のあることが示惨された。
\end{abstract}

日蓄会報，64 (7)：669-677, 1993 